\title{
THE EFFECT OF AN EDUCATIONAL INTERVENTION IN FAMILY PHISICIANS ON SELF-RATED QUALITY OF LIFE IN PATIENTS WITH MEDICALLY UNEXPLAINED SYMPTOMS
}

\author{
VPLIV EDUKATIVNE INTERVENCIJE ZDRAVNIKOV NA SAMOOCENO
} KAKOVOSTI ŽIVLJENJA, ZADOVOLJSTVA Z OBRAVNAVO IN PARTNERSKEGA ODNOSA Z ZDRAVNIKOM DRUŽINSKE MEDICINE PRI BOLNIKIH Z MEDICINSKO NEPOJASNJENIMI STANJI

\author{
Vojislav IVETIĆ1,2, Klemen PAŠIĆ ${ }^{2}$, Polona SELIČ ${ }^{*}$ \\ ${ }^{1}$ University of Maribor, Faculty of Medicine, Department of Family Medicine, Taborska 8, 2000 Maribor, Slovenia \\ 2SAVA MED, d.o.o., Cesta k Dravi 8, 2241 Spodnji Duplek, Slovenia \\ ${ }^{3}$ University of Ljubljana, Faculty of Medicine, Department of Family Medicine, \\ Poljanski nasip 58, 1000 Ljubljana, Slovenia
}

Received: May 9, 2016

Accepted: Sep 2, 2016

\section{ABSTRACT}

Keywords:

medically unexplained symptoms, family medicine, educational intervention, quality of life, treatment satisfaction, family physician-patient relationship

\section{IZVLEČEK}

Ključne besede: medicinsko nepojasnjena stanja, družinska medicina, edukacijska intervencija, kakovost življenja, zadovoljstvo bolnikov, odnos med družinskim zdravnikom in bolnikom
Introduction. Medically unexplained symptoms (MUS) are very common in family medicine, despite being a poorlydefined clinical entity. This study aimed to evaluate the effect of an educational intervention (EI) on self-rated quality of life, treatment satisfaction, and the family physician-patient relationship in patients with MUS.

Methods. In a multi-centre longitudinal intervention study, which was performed between 2012 and 2014, patients were asked to rate their quality of life, assess their depression, anxiety, stress and somatisation, complete the Hypochondriasis Index, the Medical Interview Satisfaction Scale and the Patient Enablement Instrument for assessing the physician-patient relationship, before and after the El.

Results. The mean values before and after the intervention showed that after the El, patients with MUS gave a lower (total) mean rating of their health issues and a higher rating of their quality of life, and they also had a more positive opinion of their relationship with the physician $(\mathrm{p}<0.05)$. However, there were no differences in the (total) rating of treatment satisfaction before and after the EI $(p=0.423)$. Significant differences in the symptoms in patients with MUS before and after the intervention were confirmed for stress, somatisation and hypochondriasis $(\mathrm{p}<0.05)$.

Conclusions. It could be beneficial to equip family physicians with the knowledge, skills and tools to reduce hypochondriasis and somatisation in MUS patients, which would improve patients' self-rated health status.

Uvod. V družinski medicini so medicinsko nepojasnjena stanja (MNS) pogosta, vendar slabo opredeljena klinična entiteta; od 2,5 do 25\% bolnikov, ki obiskujejo zdravnika, se pritožuje zaradi telesnih simptomov, za katere ni mogoče odkriti patofiziološkega vzroka. Namen študije je bil odkriti dejavnike, povezane s samooceno kakovosti življenja pri bolnikih z MNS v povezavi z edukativno intervencijo (EI), ki so ji bili podvrženi zdravniki.

Metode. K sodelovanju v multicentrični vzdolžni intervencijski raziskavi, ki je potekala od leta 2012 do leta 2014, je bilo povabljenih 90 zdravnikov družinske medicine, v sodelovanje jih je privolilo 63 (70\% ali 7,5\% vseh timov družinske medicine $v$ Sloveniji). Po koncu prve faze je bila polovica zdravnikov (32 od 63) povabljena na dvodnevno usposabljanje s področja prepoznavanja in obravnave bolnikov z MNS. Bolniki so pred El in po njej izpolnjevali vprašalnike o kakovosti življenja, depresiji, anksioznosti, stresu in somatizaciji, hipohondriji, zadovoljstvu in o partnerskem odnosu z zdravnikom.

Rezultati. Zdravniki so s sistematičnim vzorčenjem povabili k sodelovanju 1410 bolnikov, $v$ sodelovanje je privolilo 826 (58,58\%) bolnikov, od tega 422 z izpolnjenimi kriteriji za MNS: (1) starost (18 do 80 let), (2) zdravnikov sum in (3) izpolnjeni točkovni in klinični kriteriji za MNS (prisotnost simptoma vsaj tri mesece, klinično pomembne težave pri bolniku, nezmožnost razlage simptoma s katerokoli znano telesno boleznijo). Povprečna starost bolnikov je bila 50,35 leta $\pm 11,49$ leta, izstopale so ženske $(64,9 \%)$ in osebe z osnovnošolsko $(23,7 \%)$ in srednješolsko izobrazbo $(29,1 \%)$. Brezposelnih je bilo $28,9 \%$ bolnikov. Bolniki z MNS so po intervenciji izkazovali v povprečju nižjo (skupno) oceno težav in višjo kakovost življenja ter boljše mnenje o partnerskem odnosu z zdravnikom $(p<0,05)$, ne pa razlik $v$ (skupni) oceni zadovoljstva z obravnavo pred intervencijo in po njej $(p=0,423)$. Značilne razlike $v$ simptomih pri bolnikih z MNS pred intervencijo in po njej smo potrdili v primeru stresa, somatizacije in hipohondrije $(p<0,05)$

Zaključki. Edukacija zdravnikov je pri bolnikih z MNS izboljšala samooceno težav z zdravjem in kakovosti življenja, vplivala je na znižanje stopnje simptomov stresa, somatizacije in znižala stopnjo hipohondrije ter izboljšala mnenje bolnikov o partnerskem odnosu z zdravnikom. Do sedaj $v$ Sloveniji MNS kot ena od specifičnih vsebin dela $v$ družinski medicini niso bila dovolj raziskana, tudi pristopi k obravnavi bolnikov z MNS še niso bile oblikovani. Zdravnike bi kazalo opremiti z znanji, veščinami in orodji za zmanjševanje hipohondrije in somatizacije pri bolnikih z MNS, saj bi na ta način tudi izboljšali samooceno zdravja bolnikov. 


\section{INTRODUCTION}

Medically unexplained symptoms (MUS) are very common in family medicine despite being a poorly-defined clinical entity; approximately $2.5 \%-25 \%$ of patients who visit a family physician (FP) complain of physical symptoms for which no physical pathology can be found even after a number of examinations (1-2). The diagnosis of MUS still has a very negative connotation for patients (3). A recent Slovenian study (4) observed an $8.6 \%$ frequency of MUS in family medicine practice attendees, which shows that MUS is as much a public health care problem in Slovenia as anywhere else in the world $(1,2)$. Other Slovenian studies on the new project of model practices in family medicine did not show any more successful treatment of patients with MUS (5).

Some studies show that depression and anxiety disorders are comorbid with medically unexplained conditions (6). In the literature, MUS are often described as equivalent to somatoform disorders, but studies show that only approximately $25 \%$ of MUS patients meet the criteria for one of the somatoform disorders according to the Diagnostic and Statistical Manual of Mental Disorders, 4th Edition (DSM-IV-TR), and the 10th revision of the International Statistical Classification of Diseases and Related Health Problems (ICD-10) (7-9), which means that MUS is a problem which goes beyond the definition and criteria for somatoform disorders. Recent international studies emphasise the importance of one or more psychosocial stressors that could not be identified either by the patients or the physicians (10). Following an explanation of how such stressors can affect the occurrence of physical symptoms in patients, five areas were researched in detail, namely everyday stress and problems in life, prolonged effect/effects of childhood stress, physical manifestation of depression, posttraumatic stress disorder (PTSD), and anxiety (11).

According to the results (12), the pharmacological treatment of MUS is among the most common interventions. Also very common is the use of cognitive behavioural methods and other non-specific interventions. Cognitive behavioural approaches proved to be the most effective (12) and were confirmed (13) as being useful in reducing medically unexplained chronic fatigue in the paediatric population (aged from 11 to 18 years).

The aim of our study was to examine the effect of an educational intervention (EI) for FPs on the MUS patients' self-rated quality of life, treatment satisfaction and relationship with the physician.

\section{METHODS}

\subsection{Participants and Procedures}

\subsubsection{Participating Physicians}

A total of 90 family medicine practices or FPs from across Slovenia were invited to participate in a multi-centre longitudinal intervention study. The recruitment of the physicians was carried out between January and March 2012. The practices were selected by random sampling from the publicly available register of all Slovenian family medicine practices provided by the Institute of Public Health of the Republic of Slovenia (ZZZS) (14). This register enabled us to include in our study a population with a great socioeconomic diversity and different ethnic backgrounds. Out of 90 invited physicians, a total of 63 (70\%) decided to take part in the first phase of our study (7.5\% of all family medicine teams in Slovenia) (14).

The FPs were mailed the Study Protocol and Questionnaires. After completing the first phase of the study, half of the physicians (32 of 63) were invited to attend a two-day training on the identification and treatment of patients with MUS. All the invited physicians attended the training and were taught about the basic principles of cognitive behavioural therapy (CBT), mental illness diagnostic criteria and a proper multidisciplinary approach toward patients with MUS. Finally, a Model of Careful Assessment (MCA) as an intervention in the treatment of patients with MUS was introduced and trained. In the continuation of the study, those physicians represented the intervention group. Every three months during a 12-month period, they were sent by post a clinical vignette of a patient with MUS, which was also used in the workshops, as well as a MCA. In this way, the intervention group participants were able to refresh their newly gained knowledge. The physicians from the control group were sent only the technical instructions for the conduct of the study.

In the second phase of the study, a total of 45 (23 from the intervention group and 22 from the control group) of the participating physicians decided to continue their participation, which represented $5.36 \%$ of all family medicine teams in Slovenia (Figure 1).

In physicians, attendance at the two-day training counted as inclusion criteria for intervention group, which in fact acted as an interventional variable when following up several characteristics in MUS patients. 


\begin{tabular}{|c|c|c|c|}
\hline invited & 0 months & 12 months & \\
\hline $\begin{array}{l}90(100 \%) \\
\text { physicians }\end{array}$ & $\begin{array}{l}63(70 \%) \\
\text { physicians }\end{array}$ & $\begin{array}{l}45(50 \%) \\
\text { physicians }\end{array}$ & $45(50 \%)$ physicians \\
\hline \multicolumn{4}{|c|}{$45(50 \%)$ physicians included in the final analysis } \\
\hline
\end{tabular}

Figure 1. A graphic presentation of the number of physicians participating in either phase of the study.

\subsubsection{Participating Patients}

For three consecutive 'typical' working days, determined by the participating physicians themselves, patients aged between 18 and 80 years who came to the practice for any reason and who were suspected of MUS were invited by their physician to participate in this study. The physicians screened a total of 4,921 patients and invited 1,410 of them; $584(41.42 \%)$ of the invited patients refused to take part in the study. The most common reason for nonparticipation was lack of time.

In the end, a total of 826 (58.58\%) of patients decided to participate in the first phase of the study, with 422 of these fulfilling the criteria for MUS (patient age between 18 and 80 years, suspicion of MUS, and fulfilled criteria for MUS from Questionnaire B) and 404 patients not fulfilling the criteria for MUS. The latter were not followed-up.

In the second phase of the study (carried out between April 2012 and June 2013), 510 of the 1,410 initially invited patients (36.17\%) decided to continue their participation; of those, 269 patients had MUS. Those 269 MUS patients were analysed after the 12 -month period.

Figure 2 shows the participation of patients by the study phase.

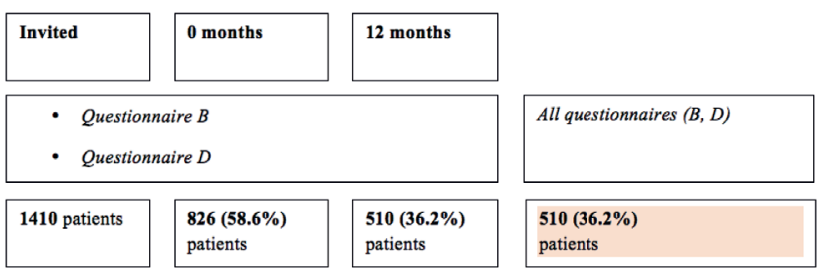

$510(36.2 \%)$ patients included in the final analysis

(they had all the data from the first and second round of the study)

Figure 2. A graphic presentation of the number of patients participating in either phase of the study.

\subsection{Instruments}

The FPs were asked to complete Questionnaire A (demographic information about the physician and practice), whereas the patients answered Questionnaire B, consisting of the PHQ-15 (Patient Health Questionnaire) for assessing the severity of non-specific somatic symptoms that have been shown to be highly associated with MUS diagnosis in the past four weeks (15), and three additional questions regarding the patients' problems and the physicians' clinical opinion (i.e., the symptom has been present for at least three months, the symptom has been causing clinically significant problems for the patient, and the symptom cannot be explained by any known physical disease) (1). A PHQ-15 score of 15 or higher and positive answers to all three additional questions formed the criteria for the inclusion of patients with MUS. The patients were also asked to complete Questionnaire $D$, which included theEQ-5D-3L (EuroQoL 5D-3L) instrument rating quality of life (16), as well as the 4DSQ (Four-Dimensional Symptom Questionnaire) for assessing depression, anxiety, stress and somatisation (17), the WI (Whiteley Hypochondriasis Index) (18), the MISS-21 (Medical Interview Satisfaction Scale) for measuring patient satisfaction (19), and the PEI (Patient Enablement Instrument) for assessing the physician-patient relationship (20).

Questionnaires A and B were completed only in the first phase of the study ( 0 months), and Questionnaire $D$ was completed at inclusion into the study ( 0 months) and 12 months later. The latest data are crucial for this study aim, providing 269 MUS patients' reflection on depression, anxiety, stress and somatisation, satisfaction, and also assessing the physician-patient relationship.

\subsection{Statistical Analysis}

Those parts of the questionnaire which were adapted from international questionnaires were assessed for their construct validity (using factor analysis) and measuring reliability. The reliability of all measures was exemplary (Cronbach's alpha $a>0.80$ ). To analyse the differences in MUS patients before and after the $\mathrm{El}$, we used the paired sample t-test for numeric variables and the chi-square test for categorical variables. Statistical significance for the entire analysis was set at a $5 \%$ risk level $(p \leq 0.05)$.

The data were statistically processed using SPSS 21.0 statistical software (IBM Corp., Grouponk, NY, USA).

\section{RESULTS}

At the beginning of the recruitment process, there were 422 patients in the group with MUS, and 404 patients in the group without MUS. 
Gender structure: The whole cohort consisted of 826 patients; $62.2 \%$ were women and $37.8 \%$ were men. The number of women was higher in the MUS patient group (64.9\%), compared to the group without MUS (59.4\%). However, this relatively higher proportion of women in the MUS group was not statistically significant $(\mathrm{x} 2=2.679$; $\mathrm{df}=1 ; \mathrm{p}=0.102$ ).

Patients' age: The mean age of patients was $49.40 \pm 12.29$ years. The mean age of patients with MUS was $50.35 \pm 11.49$ years, which is approximately two years older than the mean age of patients without MUS $(48.41 \pm 13.01$ years; $\mathrm{p}=0.040$ ).

Educational level and employment status: The MUS group included $23.7 \%$ of patients who were primary school graduates (primary school leaving age is 14 in Slovenia), whereas in the group without MUS there were $13.9 \%$ of patients with primary school only; secondary education was completed by significantly fewer patients in the MUS group (29.1\%) as compared to $38.9 \%$ of patients without MUS $(p=0.002)$. The majority of patients had completed vocational (31.7\%) and secondary (33.9\%) education; those were followed by primary education (18.9\%), postsecondary, higher or university education $(14.4 \%)$, and
Master's or Doctoral degree $(1.1 \%)$. Most patients were in employment (39.8\%), followed by retired people $(26.9 \%)$ and the unemployed $(21.3 \%) ; 9.0 \%$ of patients indicated that they were self-employed or farmers, whereas $3.0 \%$ were secondary school or university students. A statistically significant greater proportion of patients with MUS were unemployed (with MUS: 28.9\%; without MUS: $13.4 \%$ ) a smaller proportion of them were employed (with MUS: $34.1 \%$; without MUS: $45.7 \%$ ), and a smaller proportion of them had secondary school or university student status (with MUS: 1.7\%; without MUS: 4.5\%; $\mathrm{p}=0.000$ ).

Other characteristics: There were no statistically significant differences observed between the two groups of patients in terms of settlement size $(p=0.8865)$. Patients with MUS differed from others by the number of persons in the household $(p=0.028)$. In other words, patients with MUS lived in significantly larger households (3.39 \pm 1.46 members vs. $3.17 \pm 1.45$ members).

3.1 The Effect of El on Self-Rated Quality of Life, MUS, Hypochondriasis, Patient Satisfaction, and the Physician-Patient Relationship

Table 1. The analysis of differences in the (total) rating of health issues, quality of life, treatment satisfaction and the physicianpatient relationship in patients with MUS, before and after the intervention.

\section{BEFORE INTERVENTION \\ AFTER INTERVENTION}

$n=422$

$n=269$

(Total) rating of health issues

\begin{tabular}{|c|c|c|c|c|}
\hline Mean \pm standard deviation & & $8.51 \pm 1.40$ & $8.16 \pm 1.45$ & 0.000 \\
\hline \multicolumn{5}{|l|}{$95 \%$ confidence interval } \\
\hline & lower limit & 8.38 & 7.98 & \\
\hline & upper limit & 8.65 & 8.33 & \\
\hline \multicolumn{5}{|c|}{ Quality of life (self-rated health) } \\
\hline Mean \pm standard deviation & & $44.81 \pm 11.927$ & $48.21 \pm 11.722$ & 0.000 \\
\hline \multicolumn{5}{|l|}{ 95\% confidence interval } \\
\hline & lower limit & 43.67 & 46.80 & \\
\hline & upper limit & 45.95 & 49.62 & \\
\hline \multicolumn{5}{|c|}{ (Total) rating of treatment satisfaction } \\
\hline Mean \pm standard deviation & & $3.72 \pm 0.400$ & $3.71 \pm 0.304$ & 0.423 \\
\hline \multicolumn{5}{|l|}{$95 \%$ confidence interval } \\
\hline & lower limit & 3.68 & 3.68 & \\
\hline & upper limit & 3.76 & 3.75 & \\
\hline \multicolumn{5}{|c|}{ Opinion on the physician-patient relationship } \\
\hline Mean \pm standard deviation & & $2.69 \pm 0.48$ & $2.39 \pm 0.53$ & 0.000 \\
\hline \multicolumn{5}{|l|}{$95 \%$ confidence interval } \\
\hline & lower limit & 2.65 & 2.33 & \\
\hline & upper limit & 2.74 & 2.45 & \\
\hline
\end{tabular}


Table 2. The analysis of differences in the symptoms of MUS patients, and the hypochondriasis index before and after the intervention.

\begin{tabular}{|c|c|c|c|c|}
\hline & & $\begin{array}{l}\text { BEFORE INTERVENTION } \\
n=422\end{array}$ & $\begin{array}{c}\text { AFTER INTERVENTION } \\
\mathrm{n}=269\end{array}$ & $P$ \\
\hline $\begin{array}{l}\text { Depression } \\
\text { (Criterion: depression }>2 \text { ) }\end{array}$ & & $n=260(61.6 \%)$ & $n=170(63.2 \%)$ & \\
\hline Mean \pm standard deviation & & $3.92 \pm 3.270$ & $3.85 \pm 3.100$ & 0.051 \\
\hline \multicolumn{5}{|l|}{$95 \%$ confidence interval } \\
\hline & lower limit & 3.61 & 3.48 & \\
\hline & upper limit & 4.24 & 4.22 & \\
\hline
\end{tabular}

\section{Anxiety}

(Criterion: anxiety >8)

Mean \pm standard deviation

$95 \%$ confidence interval

$n=126(29.9 \%)$

$$
6.53 \pm 5.325
$$

$$
6.02
$$$$
7.04
$$

upper limit

$$
\mathrm{n}=367(87.2 \%)
$$

$19.57 \pm 7.216$

$18.64 \pm 6.701$

0.000

Mean \pm standard deviation

18.88

17.83

lower limit

upper limit

20.26

19.44

$n=77(28.6 \%)$

$6.36 \pm 5.145$

0.558

5.74

6.97
Somatisation

(Criterion: somatisation $>10$ )

Mean \pm standard deviation

95\% confidence interval $n=393(93.1 \%)$

$19.49 \pm 5.728$

18.94

20.04

$\mathrm{n}=422(100 \%)$

$45.31 \pm 9.732$

44.38

46.24 $\mathrm{n}=248(92.2 \%)$

$18.54 \pm 5.585$

0.000

17.87

19.21
Whiteley Hypochondriasis Index

Mean \pm standard deviation

$95 \%$ confidence interval lower limit
upper limit
(Table 1). Significant differences in the symptoms in patients with MUS before and after the intervention were confirmed for stress, somatisation and hypochondriasis ( $p<0.05$; Table 2).

The study topic corresponds to the current public health care policies and needs in Slovenia and around the world $(11,22,23)$. The El for physicians was prepared as a combination of several different approaches to treating patients with MUS in accordance with recommendations in the literature (21), focusing on practical work in small groups and presenting the MCA tool (24). A German study from 2007 (25) investigated the effect of a one-session 
El using a cognitive-behavioural approach, observing a reduced number of visits to practices and fewer somatisation symptoms at 6-month follow-up. In our study, the intervention's impact was evaluated through patients' self-rated quality of life, treatment satisfaction, and their assessment of the physician-patient relationship, as well as through somatisation, anxiety, depression and hypochondriasis (Table 1, Table 2 ). We could not find such criteria (as a whole) in the available body of literature.

\subsection{El and Self-Rated Quality of Life}

After the El, patients with MUS gave a lower (total) mean rating of their health issues and a higher self-rating of their quality of life (Table 1). A more recent Dutch study (26), which also employed the EQ-5D questionnaire, observed that MUS have a greater effect on the quality of life in a younger population (aged less than 65 years). A Slovenian study from 2014 (16) found that - considering the results of the EQ-5D questionnaire - the presence of psychological symptoms is associated with lower quality of life. Klemenc Ketiš et al. (16) observed a correlation between factors identified using the EQ-5D questionnaire (the presence of chronic disease, pain, and anxiety and depression), which are independently associated with psychological symptoms. In addition, findings of other authors (27) confirm the correlation between psychological and unexplained symptoms, and lower quality of life, as measured by the EQ-5D questionnaire. We reached the same conclusion with regard to the patients' quality of life, and we also confirmed the El's effect on patients with MUS in terms of their quality of life.

\subsection{El and Depression, Anxiety, Stress, and Somatisation and Hypochondriasis}

In our study, patients with MUS had a lower mean level of depression, anxiety, stress and somatisation after the $\mathrm{El}$, and this reduction in stress and somatisation was confirmed as statistically significant (Table 2). Similar to our study, the majority of other studies $(12,28)$ found that improved communication with the MUS patient is beneficial, as is the use of empathy in the physicianpatient relationship, or better acceptance of MUS patients as they are.

The analysis of differences in hypochondriasis in patients with MUS before and after the El (Table 2) confirmed that the intervention - i.e., capacity building in physicians - significantly reduced (but did not eliminate altogether) hypochondriasis in MUS patients. A recent German study from 2013 (29) analysed the effect of the El (a multidisciplinary approach and the inclusion of a psychosomatic therapist in the education of family physicians) on the treatment of MUS patients, and found a decrease in the level of hypochondriasis, which is comparable to the findings of our study.

\subsection{El and Patients' Treatment Satisfaction}

Statistical analysis did not reveal significant differences in the (total) rating of treatment satisfaction before and after the El (Table 1). Similarly, a study by Jackson, J. et al. (30) found that there were no significant differences in the treatment satisfaction of patients with MUS compared to patients without MUS. A study from Sri Lanka (31) investigated the effect of an intervention on several factors, including patients' treatment satisfaction, and showed that patient satisfaction increased after the El (mainly the education of physicians in cognitivebehavioural techniques). Differences in the findings of various authors and those of this study are probably a result of the use of different types of intervention and different questionnaires for analysing patient satisfaction; this is why the findings are difficult to compare.

\subsection{El and the Patient-Physician Relationship}

We found (Table 1) that intervention in patients with MUS significantly improved their opinion of the physicianpatient relationship. The results of our study match those of another study carried out in Scotland (32), which showed that intervention in MUS patients significantly improved their opinion of the physician-patient relationship, but failed to confirm significant differences in the (total) rating of treatment satisfaction before and after the El. We could not find any data on the intervention's effect on the physician-MUS patient relationship in comparable foreign studies $(33,34)$, which provides an opportunity for new research in this field, and for improving the quality of treatment of patients with MUS.

\subsection{Limitations of the Study}

The criteria for including patients in the group of patients with MUS are non-standardised, due to the non-existence of an accurate definition of MUS. For the purposes of this study, the inclusion criteria were based on a large review of the literature, and represented a combination of several factors to reduce this limitation. The acquisition of data excluded all physicians and patients who refused to participate in the study.

The study included patients who had visited their physician for three 'typical' working days, coming to the practice for different reasons, many due to an acute disease or the worsening of a chronic disease. Because of this, frequent visitors to family medicine practices had a greater chance of being included in the study. This study limitation could have been eliminated if we had included random sampling of patients using a register of family medicine practice patients, but the participation of patients would have most probably been even lower.

The decrease in the number of participating FPs and patients was relatively large by the end of the study, 
which is also reported by other researchers of MUS (12, 35). We also failed to track possible patterns within the MUS patients group after one-year-period, and did not analyse characteristics of the fall-out patients.

The El was relatively short (two days) and was a 'oneoff.' The El attendees were probably more motivated to participate (a personal interest in this topic) than other physicians.

The success of the El was at first limited to the observation of quality of life, treatment satisfaction and opinion of the physician-patient relationship. However, this limitation has been mitigated by the fact that quality of life was additionally evaluated based on the assessment of somatisation, depression, anxiety and hypochondriasis. The success of the El was followed up only over one-yearperiod. Unfortunately, we do not have any follow-up data for the participating physicians and patients after one year. We also do not have any follow-up data about the incidence of MUS symptoms after El, neither about the frequency of patients' attendance at family clinics.

In this study, we decided not to record the occurrence of acute diseases or the worsening frequency of chronic disease, which might have affected the self-rated quality of life in our patients.

\section{CONCLUSIONS}

Education of physicians improved the self-rating of health issues and quality of life by patients with MUS. Moreover, it also helped to reduce symptoms of stress and somatisation, and decreased the level of hypochondriasis, while also improving patients' opinion of the physicianpatient relationship. In Slovenia, MUS are still not sufficiently researched as a specific family medicine topic, and approaches to the treatment of patients with MUS have not yet been developed. Considering the results of our study, we find that it is necessary to equip FPs with knowledge, skills and tools for reducing hypochondriasis and somatisation in MUS patients. In this way, we could also improve their self-rated health status. In addition, the observed correlation with stress and anxiety highlights the necessity to manage anxiety in patients with MUS, and strengthen problem-centred strategies for managing stress.

\section{CONFLICT OF INTEREST}

The authors declare that they have no conflicts of interest.

\section{FUNDING}

This study was partly supported by the Slovenian Research Agency, Research Programme Code P3-0339.

\section{ETHICAL APPROVAL}

The study was approved by the National Medical Ethics Committee of the Republic of Slovenia, Decision No. 45/05/11bis dated 25 May 2011.

\section{REFERENCES}

1. Peveler R, Kilkenny L, Kinmonth AL. Medically unexplained physical symptoms in primary care: a comparison of self-report screening questionnaires and clinical opinion. J Psychosom Res 1997; 42: 24552.

2. Burton C. Beyond somatisation: a review of the understanding and treatment of medically unexplained physical symptoms (MUPS). Br J Gen Pract 2003; 53: 231-9.

3. Stone J, Wojcik W, Durrance D, Carson A, Lewis S, MacKenzie L, et al. What should we say to patients with symptoms unexplained by disease?: the "number needed to offend". BMJ 2002; 325: 1449-50.

4. Ivetić V. Medicinsko nepojasnjena stanja $v$ ambulanti družinske medicine: doktorska disertacija. Ljubljana: Medicinska fakulteta, 2015.

5. Poplas-Susič T, Švab I, Kersnik J. The project of model practices in family medicine in Slovenia. Zdrav Vestn 2013; 82: 635-47.

6. Schur EA, Afari N, Furberg H, Olarte M, Goldberg J, Sullivan PF, et al. Feeling bad in more ways than one: comorbidity patterns of medically unexplained and psychiatric conditions. J Gen Intern Med 2007; 22: 818-21.

7. Olde Hartman T, Hassink-Franke L, Dowrick C, Fortes S, Lam C, van der Horst $\mathrm{H}$, et al. Medically unexplained symptoms in family medicine: defining a research agenda. Proceedings from WONCA 2007. Fam Pract 2008; 25: 266-71.

8. Svetovna zdravstvena organizacija. Mednarodna klasifikacija bolezni in sorodnih zdravstvenih problemov za statistične namene: MKB10. 10. revizija. Ljubljana: Inštitut za varovanje zdravja Republike Slovenije, 1995.

9. Smith RC, Gardiner JC, Lyles JS, Sirbu C, Dwamena FC, Hodges A, et al. Exploration of DSM-IV criteria in primary care patients with medically unexplained symptoms. Psychosom Med 2005; 67: 123-9.

10. Švab I, Torres-González F, Clarke D, Stern A, Edwards T, Ivbijaro G. A three session intervention for patients with co-morbid physical and mental health problems and medically unexplained symptoms. 16th Wonca Europe conference Family Medicine into the Future Blending Health \& Cultures. Malaga, Spain, 2010.

11. Clarke DD. Solving medical mysteries: hidden stresses and unexplained symptoms. Zdr Varst 2016; 55: 152-4.

12. Sumathipala A. What is the evidence for the efficacy of treatments for somatoform disorders?: a critical review of previous intervention studies. Psychosom Med 2007; 69: 889-900.

13. Chalder T, Tong J, Deary V. Family cognitive behaviour therapy for chronic fatigue syndrome: an uncontrolled study. Arch Dis Child 2002; 86: 95-7. 
14. Zavod za zdravstveno zavarovanje Slovenije. Število opredeljenih po starostnih skupinah pri aktivnih zdravnikih SA, OD+ŠD na dan 30.11.2014. Available March 29, 2015 from: http://www.zzzs.si/ zzzs/internet/zzzs.nsf/o/6F2CAD56EE119706C125770B00390171

15. Kroenke K, Spitzer RL, Williams JB. The PHQ-15: validity of a new measure for evaluating the severity of somatic symptoms. Psychosom Med 2002; 64: 258-66.

16. Klemenc-Ketiš Z, Kuhar P, Kersnik J, Burazeri G, Czabanowska K. Self-assessment questionnaire for family doctors' assessment of quality improvement competencies: a cross-cultural adaptation in Slovenia. Zdr Varst 2014; 53: 34-41.

17. Terluin B, van Marwijk HW, Ader HJ, de Vet HC, Penninx BW, Hermens $M L$, et al. The Four-Dimensional Symptom Questionnaire (4DSQ): a validation study of a multidimensional self-report questionnaire to assess distress, depression, anxiety and somatization. BMC Psychiatry 2006; 6: 34 .

18. Speckens AE, Spinhoven P, Sloekers PP, Bolk JH, van Hemert AM. A validation study of the Whitely Index, the Illness Attitude Scales, and the Somatosensory Amplification Scale in general medical and general practice patients. J Psychosom Res 1996; 40: 95-104.

19. Meakin R, Weinman J. The 'Medical Interview Satisfaction Scale' (MISS-21) adapted for British general practice. Fam Pract 2002; 19 : 257-63.

20. Howie JG, Heaney DJ, Maxwell M, Walker JJ, Freeman GK, Rai H. Quality at general practice consultations: cross sectional survey. BMJ 1999; 319: 738-43.

21. Dowrick C. Understanding unexplained physical symptoms in primary care. Primary Care Mental Health 2005; 3: 215-9.

22. Svab I. Universality and uniqueness in family medicine. Eur J Gen Pract; 20: 91-2.

23. Ivetić V, Kersnik J, Klemenc-Ketis Z, Svab I, Kolsek M, Poplas-Susic T. Opinions of Slovenian family physicians on medically unexplained symptoms: a qualitative study. J Int Med Res 2013; 41: 705-15.

24. Walker EA, Unutzer J, Katon WJ. Understanding and caring for the distressed patient with multiple medically unexplained symptoms. J Am Board Fam Pract 1998; 11: 347-56.

25. Martin A, Rauh E, Fichter M, Rief W. A one-session treatment for patients suffering from medically unexplained symptoms in primary care: a randomized clinical trial. Psychosomatics 2007; 48: 294-303.
26. Arnold IA, Speckens AE, van Hemert AM. Medically unexplained physical symptoms: the feasibility of group cognitive-behavioural therapy in primary care. J Psychosom Res 2004; 57: 517-20.

27. Molarius A, Berglund K, Eriksson C, Eriksson HG, Linden-Bostrom M, Nordstrom E, et al. Mental health symptoms in relation to socioeconomic conditions and lifestyle factors-a population-based study in Sweden. BMC Public Health 2009; 9: 302.

28. Deary V, Chalder T, Sharpe $M$. The cognitive behavioural model of medically unexplained symptoms: a theoretical and empirical review. Clin Psychol Rev 2007; 27: 781-97.

29. 29. Schaefert R, Kaufmann C, Wild B, Schellberg D, Boelter R, Faber $R$, et al. Specific collaborative group intervention for patients with medically unexplained symptoms in general practice: a cluster randomized controlled trial. Psychother Psychosom 2013; 82: 10619.

30. Jackson J, Kincey J, Fiddler M, Creed F, Tomenson B. Differences between out-patients with physical disease and those with medically unexplained symptoms with respect to patient satisfaction, emotional distress and illness perception. Br J Health Psychol 2004; 9: 433-46.

31. Sumathipala A, Hewege S, Hanwella R, Mann AH. Randomized controlled trial of cognitive behaviour therapy for repeated consultations for medically unexplained complaints: a feasibility study in Sri Lanka. Psychol Med 2000; 30: 747-57.

32. Howie JG, Heaney DJ, Maxwell M, Walker JJ. A comparison of a Patient Enablement Instrument (PEI) against two established satisfaction scales as an outcome measure of primary care consultations. Fam Pract 1998; 15: 165-71.

33. Olde Hartman TC, Woutersen-Koch H, Van der Horst HE. Medically unexplained symptoms: evidence, guidelines, and beyond. $\mathrm{Br} \mathrm{J}$ Gen Pract 2013; 63: 625-6.

34. Hatcher S, Arroll B. Assessment and management of medically unexplained symptoms. BMJ 2008; 336: 1124-8.

35. Smith RC, Lyles JS, Gardiner JC, Sirbu C, Hodges A, Collins C, et al. Primary care clinicians treat patients with medically unexplained symptoms: a randomized controlled trial. J Gen Intern Med 2006; 21: 671-7. 